\title{
Sifat Fisik dan Kimia Pupuk dari Limbah Kulit Ubi Kayu (Manihot utillissima) dengan Aktivator Tricholant
}

\author{
Physical and Chemical Properties of Fertilizer from Cassava (Manihot Utillissima) Waste \\ with a Tricholant Activator \\ Yuanita, F. Silvi Dwi Mentari, Roby \\ Jurusan Manajemen Pertanian, Politeknik Pertanian Negeri Samarinda, Indonesia. \\ Corresponding Author: yuanita.dethe@ymail.com
}

\begin{abstract}
ABSTRAK
Limbah atau sampah adalah hasil pembuangan dari suatu proses produksi baik skala kecil maupun besar. Karena bau dan dampak negatifnya terhadap kesehatan, itu telah menjadi masalah besar di masyarakat. Salah satu masalah adalah limbah ubi kayu. Dengan banyak limbah ubi kayu yang tidak terpakai, terutama daerah penjualan gorengan di sekitar kota Samarinda. Solusi yang baik adalah membuat pupuk dari limbah ubi kayu. Tujuan dari penelitian ini adalah untuk mengamati sifat fisik pupuk (warna, bau, bentuk dan suhu) dan sifat kimia atau untuk menganalisis kandungan nutrisi pupuk dari limbah ubi kayu menggunakan aktivator tricholant dan kotoran ayam. Berdasarkan sifat fisik pupuk limbah ubi kayu (Manihot utillissima) dengan aktivator tricholant terurai pada hari ke 9 , dengan suhu stabil $27^{\circ} \mathrm{C}$, struktur remah-remah hitam, tidak berbau, dan remah-remah. Pupuk yang dihasilkan matang dan siap digunakan. Hasil analisis pupuk kimia pada perlakuan pertama (limbah ubi kayu dengan aktivator tricholant) memiliki kandungan $\mathrm{N}$ $1,20 \% \mathrm{~N}, \mathrm{P} 0,801 \%, \mathrm{~K} 0,302 \%$, rasio $\mathrm{C} / \mathrm{N} 17,35$, BO $27,17 \%$ dan $\mathrm{pH} 6,8$, pada perlakuan kedua (pencampuran limbah ubi kayu dengan campuran aktivator tricholant dan kotoran ayam) memiliki kandungan nutrisi $\mathrm{N} 0,81 \%, \mathrm{P} 0,134 \%, \mathrm{~K} \mathrm{0,235 \%}$, rasio $\mathrm{C} / \mathrm{N} 19,2$, BO $30,75 \%$ dan $\mathrm{pH} 7$. Kedua perlakuan sesuai dengan SNI 19-7030 - 2004 standar kualitas pupuk.
\end{abstract}

Kata Kunci : Limbah ubi kayu, aktivator tricholant, kotoran ayam

\begin{abstract}
Waste or rubbish is the result of disposal from a production process both small and large scale. Because of the smell and its negative impact on health, it has become a big problem in society. One problem is cassava waste. With a lot of unused cassava waste, especially fried food selling areas around the city of Samarinda. A good solution is to make fertilizer from cassava waste by mixing a tricholant activator and chicken manure. The purpose of this study is to observe the physical properties of fertilizer (color, odor, shape and temperature) and chemical properties or to analyze the nutrient content of fertilizer from cassava waste using a tricholant activator and chicken manure. Based on the physical properties of cassava (Manihot utillissima) fertilizer with a tricholant activator decompose on day 9 , with a stable temperature of $27^{\circ} \mathrm{C}$, the structure of black crumbs, odorless, and crumbs. The resulting fertilizer is ripe and ready to use. The results of the analysis of chemical fertilizers in the first treatment (cassava waste with tricholant activator) have $N$ content of $1.20 \% \mathrm{~N}, \mathrm{P} 0.801 \%, \mathrm{~K} 0.302 \%, \mathrm{C} / \mathrm{N}$ ratio $17.35, \mathrm{BO} 27.17 \%$ and $\mathrm{pH} 6.8$, in the second treatment (mixing cassava waste with a mixture of activator tricholant and chicken manure) had nutrient content of $N 0.81 \%, P 0.134 \%, K 0.235 \%, C / N$ ratio $19.2, B O 30.75 \%$ and $p H 7$ Both treatments are in accordance with SNI 19-7030 - 2004 fertilizer quality standards.
\end{abstract}

Keywords : Cassava waste, tricholant activator, chichen manure

\section{PENDAHULUAN}

Limbah adalah sisa dari aktivitas manusia dalam memanfaatkan alam yang dianggap sudah tidak berguna lagi sehingga diperlakukan sebagai barang buangan. Limbah kulit ubi kayu dikategorikan kedalam limbah padat, limbah padat dihasilkan dari rumah tangga, industri dan pertanian. Limbah padat yang berupa bahan organik apabila dibiarkan atau dibuang akan terjadi pembusukan yang berdampak pada polusi udara dan kerusakan tanah. Dari segi kesehatan, limbah padat yang tidak ditangani dapat menimbulkan penyakit dan berbahaya tidak ditangani lebih lanjut (Widyatmoko dan Sintorini, 2015).

Permasalahan limbah tidak lepas dari peranan sektor pertanian yang mempunyai peran dalam permasalahan limbah, salah 
satu solusi dari pemasalahan tersebut ialah membuat pupuk kompos.Limbah yang dihasilkan oleh sektor pertanian adalah limbah organik. Salah satu permasalahannya yang ada adalah limbah kulit ubi kayu yang tidak terpakai dan dibiarkan begitu saja dengan penjual gorengan yang ada disekitar kota Samarinda dan tidak dimanfaatkan, solusi yang baik adalah dengan menjadikan limbah tersebut sebagai pupuk kompos. Usaha ini juga sekaligus upaya menggalakkan tercapainya Zero Waste dan ramah lingkungan, mahal harga pupuk dan menghindari adanya pupuk palsu.

Ubi Kayu atau ketela pohon (Manihot utilissima) adalah tanaman perdu tahunan tropika dan subtropika dari suku Euphorbiaceae, merupakan tanaman yang banyak dibudidayakan oleh masyarakat Indonesia dan penyebarannya ditiap tempat selalu ada karena sesuai karakteristik dari ubi kayu dapat tumbuh diberbagai kondisi alam.Umbi dari ubi kayu merupakan bahan makanan tambahan bagi penduduk atau menghasilkan bahan-bahan untuk ekspor (gaplek, tepung tapioka dan sebagainya). Daun ubi kayu digunakan sebagai sayur dan juga untuk makanan ternak. Ubi kayu dapat dibuat bioethanol dan batang dapat digunakan sebagai kayu bakar.

Dalam proses pengolahan ubi kayu baik skala usaha kecil menengah (UKM) maupun skala industri, pastilah terdapat limbah padat yang berasal dari proses pembersihan ubi kayu. Limbah ubi kayu disebut onggok yaitu berupa kotoran dan kulit. Menurut Laroni (2014), presentase jumlah limbah kulit bagian luar sebesar 0,5$2 \%$ dari berat total ubi kayu segar dan limbah kulit bagian dalam sebesar $8-15 \%$. memiliki kandungan karbohidrat yang tinggi dan dapat dikomsumsi oleh manusia.

Sebagai penghasil kalori yang cukup tinggi, kulit ubi kayu merupakan salah satu dari sampah perkotaan/limbah industri yang merupakan bahan organik dan secara alami dapat terurai. Namun hal itu membutuhkan waktu cukup lama. Dalam jumlah banyak dan ditumpuk begitu saja maka limbah ubi kayu ini tidak dapat terurai dengan baik sehingga apabila dibiarkan dapat mencemari lingkungan baik tanah, air maupun udara serta menimbulkan masalah kesehatan diakibatkan bahan organik tersebut tidak terurai secara sempurna.
Pupuk merupakan hasil fermentasi atau hasil dekomposisi bahan organik seperti tanaman, hewan atau limbah bahan organik.Secara alamiah, Pupuk dapat diartikan sebagai partikel tanah yang bermuatan negatif sehingga dapat dikoagulasikan oleh kation dan partikel tanah untuk membentuk granula tanah. Pupuk dapat dibuat dari bahan yang sangat muda ditemukan disekeliling lingkungan kita, seperti sampah rumah tangga, dedaunan, jerami, alang-alang, rerumputan, sekam batang jagung dan kotoran hewan (Djuarnani dkk. 2014)

Pengomposan merupakan upaya penanggulangannya sekaligus dapat bermanfaat bagi daur hidup selanjutnya. Dengan bantuan aktivator, waktu pengomposan dapat dipersingkat, menekan biaya, menghilangkan masalah bau tak sedap dan menghasilkan pupuk dengan kualitas baik dan memenuhi syarat untuk dipergunakan sebagai pupuk organik. Oleh karena itu penelitian ini menggunakan bahan organik membuat pupuk kulit ubi kayu dicampur dengan activator tricholant untuk mempercepat proses pengomposan. Aktivator tricholant merupakan bahan yang terdiri dari enzim, asam humat, dan mikroorganisme (kultur bakteri) yang berfungsi untuk mempercepat proses penguraian bahan-bahan organik memenjadi pupuk (Sofian, 2018).

Kotoran ayam merupakan salah satu limbah yang dihasilkan baik ayam petelurmaupun ayam pedaging yang memiliki potensi yang besar sebagai pupuk organik. Kotoran ayam merupakan salah satu bahan organik yang berpengaruh terhadap sifat fisik, kimia dan pertumbuhan tanaman, juga membantu kehidupan mikroorganisme (jasad renik) bagi kesuburan tanah, seresah dan sisa-sisa tanaman diubah menjadi humus (Mul. 2015)

Penelitian ini bertujuan untuk mengamati keadaan sifat fisik pupuk (warna, bau, tekstur dan suhu kompos) dan sifat kimia atau menganalia kandungan unsur hara pupuk kompos dari kulit ubi kayu dengan menggunakan aktivaktor tricholant dan kotoran ayam. 


\section{METODE PENELITIAN}

\section{A. Waktu dan Tempat}

1. Waktu Penelitian

Penelitian ini dilaksanakan selama 4 bulan, yaitu pada bulan Agustus 2019 Oktober 2019,

\section{Tempat Penelitian}

Penelitian ini dilaksanakan di dua tempat, yaitu :

a. Pembuatan Pupukdilakukan di Laboratorium Agronomi Politeknik Pertanian Negeri Samarinda.

b. Pengujian unsur hara dilakukan di Laboratorium Tanah Politeknik Pertanian Negeri Samarinda.

\section{B. Alat dan Bahan}

Alat yang digunakan berupa parang, sekop, ember plastik, mangkuk kecil, termometer, terpal plastik, bak pengomposan dan alat tulis

Bahan yang digunakan dalam penelitian ini adalah kulit ubi kayu $(50 \mathrm{~kg})$, aktivator tricholant $(1 \mathrm{~kg})$, pupuk kandang ayam $(5 \mathrm{~kg})$ dan air.

\section{Prosedur Penelitian}

Pembuatan pupuk organik dari kulit ubi kayu meliputi langkah-langkah sebagai berikut :

1. Bahan baku berupa kulit ubi kayu dicacahsehingga halus.

2. Aktivator tricholant dilarutkan ke dalam air sesuai dosis, diaduk merata.

3. Penelitian terdiri dari 2 (dua) perlakuan adalah :

a. Perlakuan pertama : Bahan baku kulit ubi kayu $(25 \mathrm{~kg}$ ) yang sudah dicacah dan dicampur dengan aktivator tricholant $(0,5$ $\mathrm{kg})$ yang telah dilarutkan dg air hingga merata dengan kadar air $30 \%$ (dicirikan dengan bahan terasabasah bila dikepal tidak keluar air disela-sela jari dan bila dilepas akan tetap menggumpal), masukkan perlakuan pertama ke dalam kotak pembuatan kompos. Bahan tersebut selanjutnya ditutup rapat dengan terpal.

b. Perlakuan kedua : Bahan baku kulit ubi kayu $(25 \mathrm{~kg})$ yang sudah dicacah dicampur dengan kotoran ayam $(5 \mathrm{~kg})$ yang telah matangditambah aktivator tricholant $(0,5 \mathrm{~kg})$ hingga merata dengan kadar air $30 \%$ (dicirikan dengan bahan terasabasah bila dikepal tidak keluar air disela-sela jari dan bila dilepas akan tetap menggumpal), masukkan ke dalam kotak pembuatan pupuk. Bahan tersebut selanjutnya ditutup rapat dengan terpal.

4. Selama proses dekomposisi berlangsung \pm 1 (satu) minggu, temperatur dijaga dengan cara pembalikan secara teratur. Pertahankan suhu gundukan adonan 40 $50^{\circ} \mathrm{C}$, jika suhu lebih $50^{\circ} \mathrm{C}$ gundukan adonan dibolak-balik, kemudian ditutup lagi dengan terpal.

5. Dilakukan pengamatanbau, warna, tekstur dan suhu pupuk selama proses pengomposan berlangsung dan pengamatan berakhir bila pupuk telah matang ditandai dengan warna hitam, bau seperti bau tanah, tekstur remah, temperatur normal (sama dengan suhu ruangan), dan volume menyusut hingga setengahnya.

\section{Pengolahan Data}

Data hasil penelitian meliputi pengamatan fisik (warna, bau, tekstur, dan suhu), pengukuran dilakukan setiap hari, dan sifat kimia dengan pengamatan $\mathrm{C} / \mathrm{N}$ rasio, $\mathrm{pH}, \mathrm{N}$ (Nitrogen), $\mathrm{P}$ (Phosfor), $\mathrm{K}$ (Kalium) dan Bahan Organik di laboratorium setelah pupuk jadi (matang).

\section{HASIL DAN PEMBAHASAN}

A. Hasil

1. Sifat Fisik Pupuk

Waktu yang diperlukan dalam pembuatan pupuk dari limbah ubi kayu dengan pencampuran aktivaktor tricholant dan pupuk kandang adalah 9 hari pupuk yang matang ditandai dengan warna kehitaman, tidak berbau, bentuk remah (hancur bila diremas) dan suhu normal $\left(27^{\circ} \mathrm{C}\right)$

Hasil pengamatan fisik pupuk dari kulit ubi kayu dengan pencampuran aktivaktor tricholant dan pupuk kandang, pengomposan dilakukan selama 9 hari , hasil pupuk matang ditandai dengan mengenai warna, bau, bentuk dan suhu dapat dilihat pada Tabel 1 .

Dari tabel 1 menunjukkan waktu yang diperlukan dalam pembuatan pupuk dari limbah ubi kayu dengan pencampuran aktivaktor tricholant dan pupuk kandang adalah 9 hari dengan melakukan pengamatan pada warna, bau, bentuk dan suhu. Pembentukan pupuk memerlukan waktu 8 hari , pupuk yang matang ditandai 
Tabel 1. Data Harian Perubahan Warna, Bau, dan Struktur Pupuk Dari Kulit Ubi Kayu dengan pencampuran aktivaktor tricholant dan pupuk kandang

\begin{tabular}{ccccccccc}
\hline \multirow{2}{*}{ Hari } & \multicolumn{2}{c}{ Warna } & \multicolumn{2}{c}{ Bau } & \multicolumn{2}{c}{ Bentuk } & \multicolumn{2}{c}{ Suhu } \\
\cline { 2 - 9 } & PK1 & PK2 & PK1 & PK2 & PK1 & PK2 & PK1 & PK2 \\
\hline 1 & CM & CM & B & B & S & S & 27 & 27 \\
2 & CM & C & B & B & S & S & 31 & 30 \\
3 & C & C & B & B & S & S & 36 & 35 \\
4 & C & CT & KB & KB & S & S & 40 & 39 \\
5 & CT & CT & KB & KB & S & S & 51 & 43 \\
6 & CT & H & KB & KB & R & R & 36 & 37 \\
7 & H & H & TB & TB & R & R & 30 & 31 \\
8 & H & H & TB & TB & R & R & 27 & 27 \\
9 & N & H & TB & TB & R & R & 27 & 27 \\
\hline
\end{tabular}

Tabel 2. Kandungan Unsur Hara Pupuk

\begin{tabular}{cccccc}
\hline \multirow{2}{*}{ Parameter } & \multirow{5}{*}{ Satuan } & \multicolumn{5}{c}{ Kompos } \\
\cline { 3 - 6 } & & \multicolumn{2}{c}{ Hasil Penelitian } & SN1 19-7030-2004 \\
\cline { 3 - 6 } & & PK1 & PK2 & Min & Maks \\
\hline pH & $\%$ & 1,20 & 0,81 & 0,40 & - \\
Nitrogen (N) & $\%$ & 0,801 & 0,134 & 0,10 & - \\
Phosfor (P) & $\%$ & 0,302 & 0,235 & 0,20 & - \\
Kalium (K) & - & 17,35 & 19,2 & 10 & 20 \\
C/N & $\%$ & 27,17 & 30,75 & 27 & 58 \\
Bahan Organik & & & & &
\end{tabular}

Sumber : Data Primer (2019)

dengan warna kehitaman, tidak berbau, bentuk remah (hancur bila diremas) dan suhu normal $\left(27^{\circ} \mathrm{C}\right)$

\section{Sifat Kimia Pupuk}

Hasil uji laboratorium unsur hara yang terkandung dalam bahan baku pupuk hasil penelitian yang telah matang dibandingkan dengan unsur hara pupuk standar kualitas pupuk SNI 19-7030-2004 dapat dilihat pada tabel 2.

Dari tabel 2 pada perlakuan 1 (PK1) menunjukkan adanya peningkatan unsur hara pupuk dari limbah kulit ubi kayu dengan aktivaktor tricholant yang telah dikomposkan selama 9 hari terutama unsur Nitrogen $(\mathrm{N})$ sebesar 1,20, Phosfor (P) sebesar 0,801, Kalium (K) sebesar 0,302, C/N sebesar 17,35 , dan yang menurun adalah Bahan Organik (BO) sebesar 27,17.

Pada perlakuan 2 (PK2) menunjukkan adanya peningkatan unsur hara pupuk dari limbah kulit ubi kayu dengan pencampuran aktivaktor tricholant dan kotoran ayam yang telah dikomposkan selama 9 hari terutama unsur Nitrogen $(N)$ sebesar 0,81 , Phosfor $(P)$ sebesar 0,134, Kalium (K) sebesar 0,235, $\mathrm{C} / \mathrm{N}$ sebesar 19,2 dan Bahan Organik (BO) sebesar 30,75 . 


\section{B. Pembahasan}

\section{Hasil Analisis Fisik Pupuk}

Hasil analisis fisik pupuk, pengomposan ini dilakukan selama 10 hari. Secara visual kematangan pupuk dari kulit ubi kayu dengan campuran aktivaktor tricholant dan pupuk kandang dapat diketahui antara lain dari:

a. Bau

Pada awal pengomposan tercium bau tidak sedap dan sudah matang berbau harum seperti tanah. Hal ini diduga terhambatnya aerasi sehingga terjadi proses anaerob yang menghasilkan bau tidak sedap Proses anaerob akan menghasilkan senyawasenyawa yang berbau tidak sedap seperti asam-asam organik, amonia, dan $\mathrm{H}_{2} \mathrm{~S}$ (Isroi, 2019). Aerasi dapat ditingkatkan dengan melakukan pembalikan pada tumpukan pupuk.

b. Warna

Warna pupuk yang sudah matang adalah hitam. Perubahan warna dari coklat pada awal pengomposan hingga kehitaman pada akhir pengomposan disebabkan oleh terdekomposisinya bahan organik dengan adanya mikroorganisme dari aktivaktor tricholant dan pupuk kandang adanya proses dekomposisi aerob sehingga terjadinya perubahan warna pada pupuk menjadi kehitaman (Sutanto, 2019).

c. Suhu

Tinggi rendahnya suhu ternyata merupakan faktor yang sangat berpengaruh terhadap keberhasilan pembuatan kompos. Peningkatan suhu pada umumnya terjadi sejak awal pembuatan pupuk. Peningkatan tersebut dapat berubah-ubah dari suhu 27$50^{\circ} \mathrm{C}$ (Murbandono. 2016). Selanjutnya mendekati dengan suhu awal pengomposan yang merupakan indikasi bahwa kompos sudah matang. Pernyataan tersebut diperkuat oleh Isroi (2019), di mana suhu meningkat pada awal pengomposan $\left(\geq 30^{\circ} \mathrm{C}\right)$ dan akan tetap tinggi selama waktu tertentu. hal ini menunjukkan terjadinya dekomposisi/penguraian bahan organik yang sangat aktif. Mikroba-mikroba di dalam kompos dengan menggunakan oksigen akan menguraikan bahan organik menjadi $\mathrm{CO}_{2}$, uap air dan panas. Setelah sebagian besar bahan telah terurai, maka suhu akan berangsur-angsur mengalami penurunan. Pada saat itu terjadi pematangan kompos, yaitu pembentukan komplek liat humus.

\section{d. Struktur}

Pupuk yang telah matang bersifat remah, akan terasa lunak ketika dihancurkan, ketika diremas-remas akan mudah hancur dan terjadi penyusutan volume/bobot pupuk seiring dengan kematangan pupuk. Penyusutan pupuk dari kulit ubi kayu dengan menggunakan aktivaktor tricholant dan pupuk kandang bisa $40-50 \%$. Bahan baku pupuk yang digunakan dengan adanya campuran bahan lain berpengaruh pada proses penguraian dekomposisi relatif lebih cepat dibandingkan bahan baku sejenis (Murbandono, 2016).

\section{Hasil Analisis Kimia Pupuk}

a. $\mathrm{pH}$

Menurut Rosmarkamdan Yuwono, bahwa $\mathrm{pH}$ yang baik pada pupuk yang telah matang antara 5,5 - 7,5 (netral). Pada penelitian ini kisaran $\mathrm{pH}$ selama proses pengomposan mengalami fluktuasi $(6,1-7)$. $\mathrm{pH}$ akhir hasil proses pengomposan dari PK1 adalah 6,8 sedangkan $\mathrm{pH}$ akhir hasil proses pengomposan dari PK2 adalah 7.Rendah $\mathrm{pH}$ akhir dari kompos PK1 dibandingkan dengan kompos PK2 diduga disebabkan pada contoh PK1 tersebut pada saat proses pengomposan berlangsung dikarenakan adanya asam-asam organik dan anorganik yang dihasilkan, sehingga menyebabkan ionion $\mathrm{H}^{+}$yang terdapat pada kompos terlepas dan menyebabkan reaksi kompos menurun. b. Nitrogen (N)

Dari hasil penelitian nilai Nitrogen $(\mathrm{N})$ adalah sebesar $1,20 \%$ dan $0,81 \%$, berdasarkan nilai tersebut maka kompos dari limbah ubi kayusudah memenuhi Standar Nasional Indonesia (SNI) 19-7030-2004 sebesar $0,40 \%$. Hali ini diduga karena adanya aktifitas mokroorganisme dalam menguraikan bahan dalam kompos dengan menggunakan aktivator yang mengandung bahan aktif Trichoderma Sp. berkerja secara efektif dalam proses pengomposan dan dapat menekan mikroorganisme, sehingga dapat mempercepat perombakan bahan organik, menghancurkan bahan organik seperti lingnin dan selulosa tanpa menimbulkan senyawa beracun, sedangkan bakteri fotosintetik dapat meningkat nitrogen dari udara (Nugroho. 2016).

c. Fosfor $(P)$

Nilai fosfor $(P)$ pada pupuk adalah

0,801 dan $0.134 \%$, berdasarkan nilai 
tersebut pupuk dari limbah ubi kayusudah memenuhi Standar Nasional Indonesia (SNI) 19-7030-2004 sebesar 0,10\%. Hal ini diduga adanya aktifitas mikroorganisme dalam menguraikan bahan aktivator yang mengandung bahan aktif Trichoderma Sp. menjadi asam laktat, sehingga menjadi asam menyebabkan fosfor yang terikat dalam rantai panjang akan larut dalam asam organik yang dihasilkan oleh mikroorganisme tersebut, dan lebih banyak unsur hara fosfor (Nugroho, 2016).

d. Kalium (K)

Nilai Kalium (K) pada pupuk dari limbah ubi kayu adalah 0,302 dan 0,235 \%, berdasarkan nilai tersebut sudah memenuhi Standar Nasional Indonesia (SNI) 19-70302004 sebesar 0,20 \%. Hal ini diduga karena pada penggunaan aktivator yang mengandung bahan aktif Trichoderma Sp memiliki mikroorganisme lebih banyak untuk melakukan proses pendegradasi yang menyebabkan rantai karbon yang lebih sederhana unsur kalium meningkat. Menurut Djaja (2018) kalium merupakan senyawa yang di hasilkan oleh mikroorganisme bakteri dimana bakteri ion-ion $\mathrm{K}^{+}$bebas ada pada bahan pembuatatan kompos untuk keperluan metabolisma, sehingga pada hasil fermentasi kalium akan meningkat dengan semakin berkembangnya jumlah bakteri yang ada dalam bahan penyusun kompos.

e. C/N Rasio

Nisbah karbon dan nitrogen (nisbah $\mathrm{C} / \mathrm{N}$ ) sangat penting untukunsur hara yang diperlukan oleh mikroorganisme selama proses pengomposan berlangsung. Karbon diperlukan oleh mikroorganisme sebagai sumber energi dan nitrogen untuk membentuk protein. Menurut Sutanto (2019) apabila ketersediaan karbon berlebihan $(\mathrm{C} / \mathrm{N}>40)$ jumlah nitogen sangat terbatas sehingga merupakan faktor pembatas pertumbuhan mikroorganisme. Nisbah $\mathrm{C} / \mathrm{N}$ yang cukup besar juga menunjukkan sebagai bahan yang sukar terdekomposisi. Penggunaan aktivator yang mengandung bahan aktif Trichoderma sp. mempunyai kemampuan untuk menghancurkan bahan organik dalam waktu yang singkat. Mikroba ini mengeluarkan enzim penghancur lignin dan selulosa. Dengan hancurnya lignin dan selulosa, kadar karbon akan turun dan kadar nitrogen meningkat sehingga $\mathrm{C} / \mathrm{N}$ menjadi kecil (Indriani, 2015).
Uji kematangan pupuk dilakukan dengan uji laboratorium dengan kematangan pupuk adalah nisbah $\mathrm{C} / \mathrm{N}$. Apabila nisbah $\mathrm{C} / \mathrm{N}$ kompos 20 atau lebih kecil berarti kompos tersebut siap digunakan (Sutanto, 2019). Pupuk hasil penelitian PK1 (limbah kulit ubi kayu dengan aktivaktor tricholant) C/N 17,35 dan PK2 (limbah kulit ubi kayu dengan campuran aktivaktor tricholant dan kotoran ayam) memiliki nilai C/N 19,20. Hasil analisis persyaratandengan standar kualitas pupuk SNI 19-7030-2004.

f. Bahan Organik (BO)

Nilai bahan organik adalah 27,17 dan 30,75 berdasarkan nilai tersebut sudah memenuhi Standar Nasional Indonesia (SNI) 19-7030-2004 sebesar 0,20 \%. Hal ini diduga bahan organik penambahan aktivaktor tricholant dan kotoran ayam lebih cepat mengalami proses pengomposan karena ada mikroorganisme yang dapat meningkatkan BO pada saat pupuk matang. Sesuai dengan pendapat Muzaiyanah dan Subandi (2016), pada bahan organik sudah mengandung unsur hara yang cukup dan ditambahkan unsur yang lain untuk mempercepat pengomposan dirombak oleh mikroorganisme maka proses dekomposisi akan mempercepat pengompoosan.

\section{KESIMPULAN DAN SARAN}

A. Kesimpulan

1. Hasil analisis fisik pupuk dari limbah kulit ubi kayu sebagai bahan dasar pupuk dipercepat dengan tambahan aktivator tricholant dan kotoran ayam proses pengomposan berlangsung selama 9 hari hingga matang, terlihat dari warna kehitaman, tidak berbau, bentuk remah (hancur bila diremas) dan suhu normal $\left(27^{\circ} \mathrm{C}\right)$

2. Pupuk dari kulit ubi kayu dengan pencampuran aktivaktor tricholant dan kotoran ayam yang dihasilkan telah matang dan siap digunakan. Pupuk dengan perlakuan pertama (mencampur cacahan kulit ubi kayu dengan aktivaktor tricholant) mempunyai kandungan unsur hara $\mathrm{N} 1,20 \%, \mathrm{P} 0,801 \%, \mathrm{~K} 0,302 \%$, nisbah $\mathrm{C} / \mathrm{N} 17,35$, BO 27,17\% serta $\mathrm{pH}$ 6,8 dan pupuk dengan perlakuan kedua (mencampur cacahan kulit ubi kayu,aktivaktor tricholant dan kotoran ayam) mempunyai kandungan unsur hara $\mathrm{N} 0,81 \%, \mathrm{P} 0,134 \%, \mathrm{~K} \quad 0,235 \%$, 
nisbah $\mathrm{C} / \mathrm{N} 19,2$, BO $30,75 \%$ serta $\mathrm{pH} 7$ sesuai dengan standar kualitas pupuk SNI 19-7030-2004.

\section{DAFTAR PUSTAKA}

Djaja.W .2018. Langkah Jitu Membuat Kompos dari Kotoran Ternak dan Sampah. AgroMedia Pustaka. Jakarta

Djuarnani, N, Kristian dan Setiawan, B.S. 2014. Cara Cepat Membuat Kompos. Agromedia Pustaka. Jakarta.

Indriani, Y.H. 2015. Membuat Kompos Secara Kilat. Penebar Swadaya. Jakarta

Isroi. 2019. Kompos. Balai Penelitian Bioteknologi Perkebunan Indonesia. Bogor

Mul.M.S. 2015. Pupuk Dan Cara Pemupukan. Rineka Cipta. Jakarta

Murbandono.L . 2016. Membuat Kompos. Penebar Swadaya. Jakarta

Muzaiyanah.S dan Subandi . 2016. Peranan Bahan Organik dalam
PeningkatanProduksi Kedelai dan Ubi Kayu pada Lahan Kering MasamBalai Penelitian Kacang-kacangan dan Umbi-umbian.Malang. Jurnal Penelitian Pertanian Tanaman Pangan.

Nugroho.P. 2016. Panduan Membuat Kompos Cair. Pustaka Baru Press. Jogja

Rosmarkam, A. dan Yuwono, N.W. 2015. IImu Kesuburan Tanah. Kanisius. Jakarta.

Laroni, J.I. 2014.Jurnal Pemanfaatan Kulit Ubi Kayu Sebagai Biosorben Logam Fe.Palu. Jurusan Kimia FMIPAUniversitas Tadulako .

Sofian. 2018. Sukses Membuat Kompos dari Sampah. PT. AgroMedia Pustaka. Jakarta

Sutanto, R. 2019. Penerapan Pertanian Organik. Kanisius. Yogyakarta.

Widyatmoko, H. dan Sintorini. 2015. Menghindari, Mengolah dan Menyingkirkan Sampah. Abdi Tandur. Jakarta. 